\title{
Tomato spotted wilt virus infects spider lily plants in Australia
}

\author{
Ralf G. Dietzgen $^{1}$ (D) Juliana Freitas-Astúa ${ }^{2,3} \cdot$ Renato B. Salaroli ${ }^{4} \cdot$ Elliot W. Kitajima $^{4}$
}

Received: 24 May 2018 / Accepted: 24 July 2018 / Published online: 31 July 2018

(C) Australasian Plant Pathology Society Inc. 2018

\begin{abstract}
Tomato spotted wilt virus (TSWV) was identified in green red-rimmed ringspots on spider lily (Hymenocallis spp.) leaves in Brisbane, Australia. Tospovirus-like particles were seen in thin sections of those lesions. RT-PCR using tospovirus-specific primers amplified a DNA fragment whose sequence matched TSWV S RNA. The virus caused symptoms in Nicotiana benthamiana following mechanical transmission and was confirmed as TSWV by RT-PCR.
\end{abstract}

Keywords Orthotospovirus $\cdot$ Ornamental plant $\cdot$ Ringspots $\cdot$ Hymenocallis spp. $\cdot$ TSWV

Spider lily is the common name for several plant species in the family Amaryllidaceae. The genus Hymenocallis contains over 60 species of herbaceous, bulbous perennial ornamental plants that are native to the warmer regions of the Americas and the Caribbean (Kew Science 2017). A number of tospoviruses (genus Orthotospovirus, family Tospoviridae, order Bunyavirales) have been shown to infect spider lilies, often causing concentric chlorotic ringspots on infected leaves, including calla lily chlorotic spot virus (Liu et al. 2012), hippeastrum chlorotic ringspot virus (Xu et al. 2013), impatiens necrotic spot virus (Liu et al. 2010), and capsicum chlorosis virus (Huang et al. 2017). A review of the host range of tomato spotted wilt virus (TSWV) by Parrella et al. (2003) lists four Hymenocallis species named in a textbook by Edwardson and Christie (1997) as species reported to be infected by TSWV, but without information on symptomatology and geographic location. The reference given by Edwardson and Christie however does not list any Hymenocallis species

Ralf G. Dietzgen

r.dietzgen@uq.edu.au

1 Queensland Alliance for Agriculture and Food Innovation, The University of Queensland, Qld, St. Lucia 4072, Australia

2 Embrapa Cassava and Fruits, Cruz das Almas, BA 44380-000, Brazil

3 Instituto Biológico, Av. Cons. Rodrigues Alves 1252, São Paulo, SP 04014-900, Brazil

4 Departmento de Fitopatologia e Nematologia, ESALQ/USP, Piracicaba, SP 13418-900, Brazil as hosts (Klinkowski and Uschdraweit 1968) casting doubt on the accuracy of this report. During a survey of ornamental plants in September 2017, we observed a planting of spider lilies (Hymenocallis spp.) with striking chlorotic ringspots rimmed by dark red margins at the Mount Coot-tha Botanical Garden in Brisbane, Australia (Fig. 1). This prompted us to investigate if a tospovirus was associated with this disease.

Small sections from the lesions of collected leaf samples were fixed in $2.5 \%$ glutaraldehyde and $2 \%$ paraformaldehyde in $0.05 \mathrm{M}$ cacodylate buffer, $\mathrm{pH} 7.2$ [Electron Microscopy Science (EMS), Hatfield, PA, USA] and post-fixed in $1 \%$ $\mathrm{OsO}_{4}$ (EMS), dehydrated in ethanol and embedded in low viscosity Spurr's epoxy resin (EMS). Thin sections from the embedded tissues were obtained using a Leica EM UC6 ultramicrotome equipped with Diatome diamond knife, mounted on 300 mesh copper grids and stained with $3 \%$ uranyl acetate and Reynold's lead citrate (EMS) (Kitajima and Nome 1999). Stained tissue sections were examined in a JEOL JEM 1011 transmission electron microscope and the images recorded digitally. Membrane-bounded, roundish particles, 80 $100 \mathrm{~nm}$ in diameter, typical of tospoviruses, were consistently found in cisternae of the endoplasmic reticulum in many epidermal and parenchymal cells of the tissues from the lesions (Fig. 2).

Total RNA was extracted from ringspot lesions using RNeasy Plant Mini kit (Qiagen). Superscript One-Step RTPCR system with Platinum Taq DNA polymerase (Thermo Fisher Scientific) was used following the manufacturer's protocol and primer pair AM1-F and AM1-R using an annealing 
Fig. 1 Spider lily planting (right) and close up (left) showing green ringspots with bright red margins on the leaves. Mt. Coot-tha Botanical Garden, Brisbane

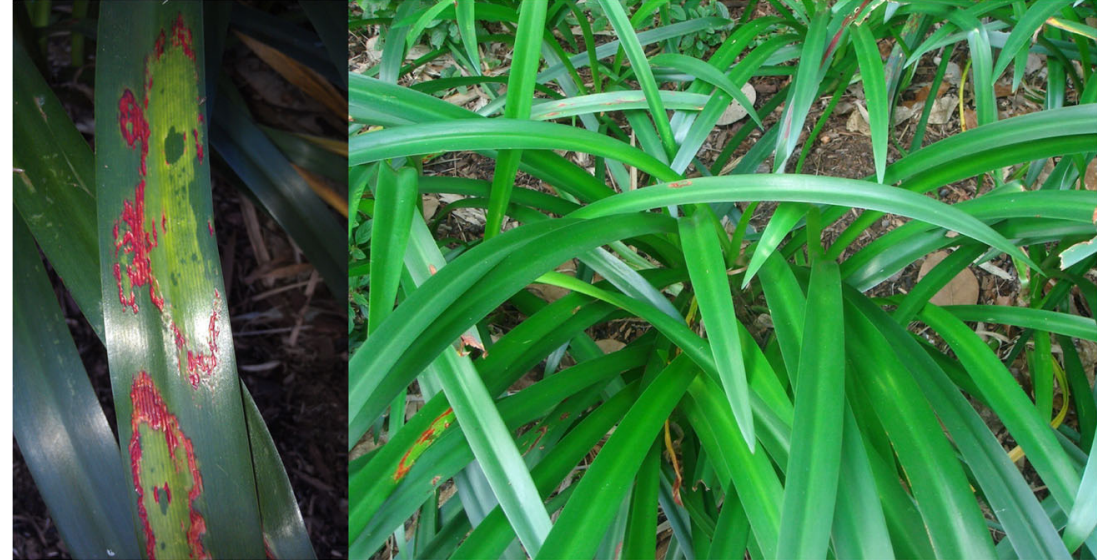

temperature of $50{ }^{\circ} \mathrm{C}$ (Hassani-Mehraban et al. 2016). A single amplicon of $763 \mathrm{bp}$ was obtained, similar in size to the product obtained with TSWV RNA control (data not shown). Amplified DNA was purified using Wizard SV Gel and PCR clean up kit (Promega), cloned into pGEM-T easy vector (Promega) and transformed into Omnimax E. coli competent cells following the manufacturer's protocols. Following colony PCR, four positive recombinant clones were grown overnight and plasmid DNA was extracted for Sanger sequencing using M13 forward and reverse primers at the Australian Genome Research Facility (Brisbane). The tospovirus infecting spider lily was identified as TSWV based on PCR amplification of a fragment of S RNA using generic American clade tospovirus-specific primers (Hassani-Mehraban et al. 2016) and on the nucleotide sequence of this fragment that was deposited as GenBank accession MG81238. In a Blast N search on NCBI, the TSWV S RNA fragment amplified from spider lily was $99 \%$ identical to S RNA sequences from 20 different TSWV accessions.

Freshly collected spider lily leaf lesions were cut into small pieces, ground in a mortar and pestle in $10 \mathrm{mM}$ phosphate buffer, pH 7.6 and rub-inoculated onto carborundum-dusted leaves of Nicotiana benthamiana plants; control plants were inoculated with buffer only. Plants were maintained in a growth cabinet at $25{ }^{\circ} \mathrm{C}$ with $16 / 8 \mathrm{~h}$ day/night cycle. New leaves displayed chlorosis and downward curling symptoms 14 days post inoculation (Fig. 3a) when leaf disks were collected and stored at $-80^{\circ} \mathrm{C}$. Total RNA was extracted using RNeasy Plant Mini kit and TSWV S RNA was detected using RT-PCR as described above. RNA extracts from symptomatic spider lily and inoculated $N$. benthamiana leaves were positive for TSWV based on a single 763 bp band in 1\% agarose/TBE gel similar in size to the TSWV positive control, whereas extracts from mock-inoculated $N$. benthamiana and no template control lanes showed no bands (Fig. 3b).

We conclude that TSWV is associated with the striking redgreen ringspots on spider lily and that this isolate was mechanically transmissible to the known experimental host $N$. benthamiana where TSWV replicated, moved systemically and caused symptoms. To the best of our knowledge this is the first Australian report of TSWV infecting Hymenocallis species.
Fig. 2 Transmission electron micrograph images showing tospovirus-like particles in parenchymal cells of ringspot lesions on leaves of spider lily plants from Mt. Coot-tha Botanical Garden a

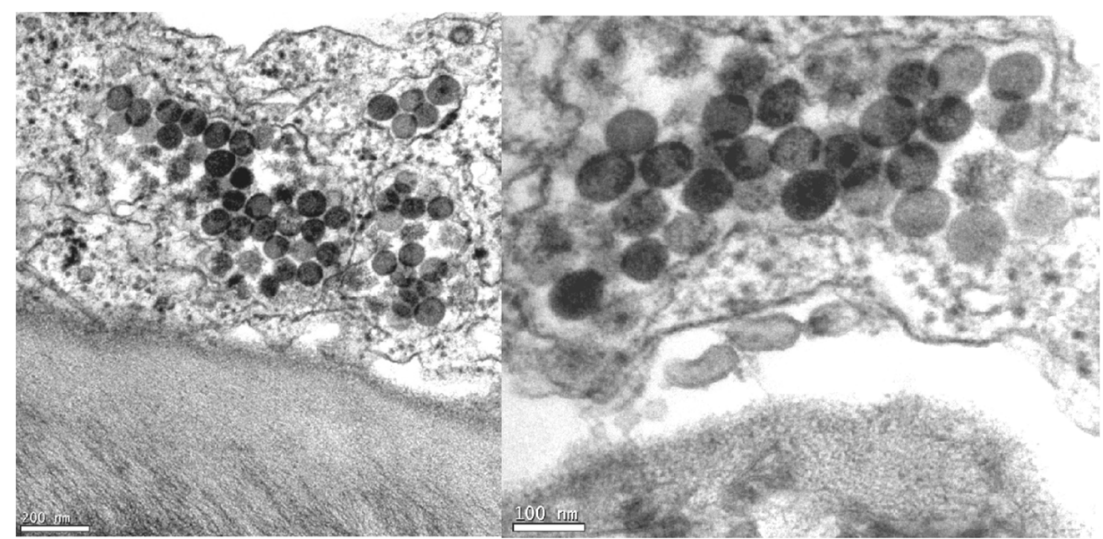


a
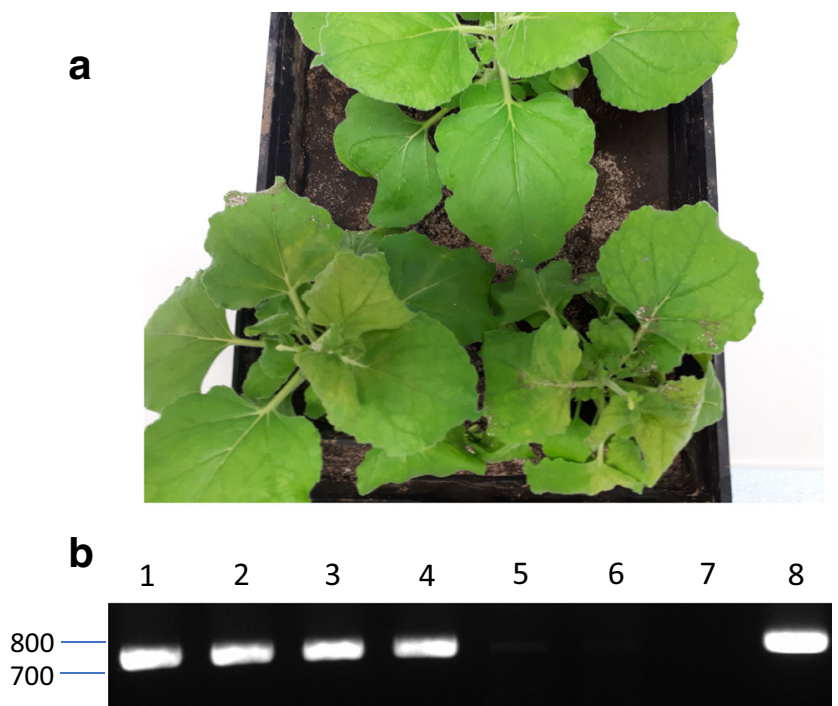

Fig. 3 Transmission of TSWV from spider lily to Nicotiana benthamiana. (a) N. benthamiana plants 14 days post inoculation with spider lily ringspot tissue (bottom) or buffer (top); (b) TSWV RT-PCR of total RNA extracts analysed by $1 \%$ agarose/TBE gel electrophoresis. DNA size markers (basepairs), 1, 2, symptomatic spider lily; 3, 4, spider lily sap-inoculated $N$. benthamiana; 5, 6, mock-inoculated $N$. benthamiana; 7 , no template control; 8 , TSWV positive control

Acknowledgements This research was jointly supported by the Queensland Department of Agriculture and Fisheries and the University of Queensland through the Queensland Alliance for Agriculture and Food Innovation. Reciprocal travel and collaboration was supported by FAPESP-UQ SPRINT grant 2017/50039-1. We thank the friendly volunteers at the Gardens for their interest and assistance in identifying the genus of spider lily.

\section{Compliance with ethical standards}

Conflicts of interest The authors have no conflicts of interest.
Human and animal rights and informed consent This article does not contain any studies with human participants or animals performed by any of the authors.

\section{References}

Edwardson JR, Christie RG (1997) Tospovirus. In: Viruses infecting peppers and other solanaceous crops, vol 2. University of Florida, Agricultural Experiment Station, Gainesville, pp 687-719

Hassani-Mehraban A, Westenberg M, Verhoeven JTJ, van de Vossenberg BTLH, Kormelink R, Roenhorst JW (2016) Generic RT-PCR tests for detection and identification of tospoviruses. J Virol Methods 233:89-96

Huang Y, Hong H, Zhao XH, Li J, Tao XR (2017) Complete genome sequence of a Capsicum chlorosis virus in China and the structural variation and evolutionary origin of its S RNA intergenic region. Arch Virol 162:3229-3232

Kew Science. The Board of Trustees of the Royal Botanic Gardens, Kew (2017) World Checklist of Selected Plant Families, retrieved 2017 12-29, search for "Hymenocallis" http://wcsp.science.kew.org/ prepareChecklist.do?checklist=selected_families $\% 40 \%$ 40363291220171103492

Kitajima EW, Nome C (1999) Microscopia electronica en virologia vegetal. In: Do Campo D, Lenardon S (eds) Métodos para detectar patógenos sistémicos. Córdoba, INTA/IFFIVE, pp 59-87

Klinkowski M, Uschdraweit HÁ (1968) Die Bronzefleckenkrankheit der Tomate. In: Klinkowski M (ed) Pflanzliche Virologie II. Akademie Verlag, Berlin, pp 45-47

Liu YT, Zheng YX, Li YZ, Li ZY (2010) First report of Impatiens necrotic spot virus on Spiderlily in China. Plant Dis 94:484

Liu Y, Lu X, Zhi L, Zheng Y, Chen X, Xu Y, Wu F, Li Y (2012) Calla lily chlorotic spot virus from spider lily (Hymenocallis litteralis) and tobacco (Nicotiana tabacum) in the south-west of China. J Phytopathol 160:201-205

Parrella G, Gagnalons P, Gebre-Selassie K, Vovlas C, Marchoux G (2003) An update on the host range of tomato spotted wilt virus. J Plant Pathol 85:227-264

Xu Y, Lou S, Li X, Zheng Y, Wang W, Liu Y (2013) The complete S RNA and M RNA nucleotide sequences of a hippeastrum chlorotic ringspot virus (HCRV) isolate from Hymenocallis littoralis (Jacq.) Salisb in China. Arch Virol 158:2597-2601 